\section{Førerkortvurderinger - behov for samordning og utvikling}

I Tidsskriftet nr. 13-14/2010 ga Brækhus og medarbeidere et viktig bidrag til temaet førerkortvurderinger (1). Deres studie omhandler legenes dobbeltrolle, som oppleves som konfliktfylt. Mange leger synes helsemessig egnethet for kjøring er vanskelig å vurdere, bl.a. med tanke på rus- og alkoholmisbruk, psykiatrisk sykdom, høy alder og medikamentbruk. Det er særlig krevende der det er kognitiv svikt. Mange finner regelverket vanskelig.

Helsevurderinger for førerkort omhandler risikovurdering. Mange faktorer samvirker, deriblant premorbide faktorer som tidligere kjøreatferd, personlighetsstil og tegn på kognitiv svikt samt personens evne til å kompensere ved hjelp av innsikt i egen funksjon og begrensninger (2).

Vi har lite kunnskap om hvorvidt de som klareres, utgjør en trafikkrisiko fordi det foreligger få forløpsstudier. Praktiske kjøretester er blitt regnet som gullstandard, men deres validitet som prediktor for ulykker er usikker. Brækhus og medarbeideres studie indikerer at det er en betydelig ulik praksis i legers helsevurdering av egnethet for førerkort, med forskjellsbehandling som konsekvens.

Arbeidet med å sikre en mer lik praksis må foregå på flere områder. Det er behov for klarere retningslinjer fra myndighetene. Det må sikres lik praksis på fylkesmannsnivå. Det må etableres konsensus om hvordan førerkortvurderinger skal foretas. En faglig veileder for psykologer er for tiden under utarbeiding. Det må utarbeides kurs for fastleger og spesialister samt for psykologer og optikere, som også har meldeplikt etter helsepersonelloven. Det må etableres klarere retningslinjer og kriterier for hvor pasienten kan henvises dersom vurderende lege er i tvil.

Trafikkmedisinske sentere anføres som en mulig løsning. Slike kan organiseres på ulike måter. Én modell er sentere innen spesialisthelsetjenesten med spisskompetanse på førerkortvurderinger ut fra enkelte problemstillinger som rus, psykiatrisk sykdom eller kognitiv funksjonsnedsettelse. Ved Sunnaas sykehus gjøres det eksempelvis ca. 600 førerkortvurderinger årlig av både innlagte og henviste pasienter, hovedsakelig der det er spørsmål om kognitiv egnethet. Miljøet er en aktiv bidragsyter til klinisk utvikling og forskning på området $(3,4)$.
Tilgangen på spesialistvurderinger bør trolig økes innen de ulike helseregioner. Uansett organisering må vurderingene samordnes flerregionalt, slik at det etableres en mer ensartet praksis. Dette krever tverrregionalt samarbeid mellom profesjonene og i forhold til aktuelle forvaltningsorganer som Helsedirektoratet, Veidirektoratet og fylkesmennene.

\section{Anne-Kristine Schanke \\ Frank Becker \\ Per Egil Østen \\ Andreas Schillinger \\ Sunnaas sykehus \\ Litteratur \\ 1. Brækhus A, Bruun Wyller T, Engedal K. Legers syn på helsevurdering for førerkort. Tidsskr Nor Lege- foren 2010; 130: 1343-6. \\ 2. Pietrapiana $P$, Tamietto $M$, Torrini $G$ et al. Role of premorbid factors in predicting safe return to driv- ing after severe TBI. Brain Inj 2005; 19: 197-211. \\ 3. Schanke AK, Rike PO, Mølmen A et al. Driving behaviour after brain injury: a follow-up of acci- dent rate and driving patterns $6-9$ years post- injury. J Rehab Med 2008; 40: 733-6. \\ 4. Mosberg A, Østen PE, Schanke AK. Bilkjøring etter hjerneskade. Tidsskr Nor Legeforen 2000; 120: 3392-5.}

\section{Andreas Austgulen Westin}

\section{Ja, pregabalin kan misbrukes!}

Jørgen Bramness påpeker i Tidsskriftet nr. 17/2010 at pregabalin fortsatt må overvåkes med tanke på misbrukspotensial (1). Med erfaringer fra rusomsorgen deler vi hans oppfatning, og presenterer her en kasuistikk som understøtter dette.

En kvinne i 30-årene ble etter eget ønske innlagt på avrusningsklinikk for seponering av zopiklon (Imovane) og pregabalin (Lyrica). Hun hadde brukt begge de to midlene i ca. to år for henholdsvis insomni og generalisert angstlidelse. Forskrevne døgndoser på innleggelsestidspunktet var henholdsvis 7,5 mg og $600 \mathrm{mg}$, men pasienten innrømmet å kunne innta tredoble doser for å oppnå ruseffekt. Hun anga at zopiklon og pregabalin «styrte livet hennes», og at «de tolv timene mellom dosene føltes som et halvår». Forsøk på å la hjemmesykepleien administrere pregabalindoseringen hadde feilet, da pasienten selv oppsøkte apoteket og fikk utlevert medikamentet. Pasienten sa at pregabalin ga henne rus, og hun var usikker på om hun kunne klare seg uten.

På avrusningsklinikken ble zopiklon bråseponert, mens pregabalin ble trappet ned med $50 \mathrm{mg}$ hver annen dag. Etter drøyt
Avdeling for klinisk farmakologi

St. Olavs hospital

to uker var hun nede i en døgndose på kun $50 \mathrm{mg}$, men hun opplevde da sterk angst og kroppslige symptomer, og man økte dosen til $150 \mathrm{mg}$ for å unngå at hun avbrøt behandlingen. Etter ytterligere en uke lyktes man i å seponere pregabalin helt, og pasienten ble utskrevet.

I den norske preparatomtalen av pregabalin er det anført at legemidlet kan gi eufori, men ordet «rus» er ikke brukt (2). I samme preparatomtale er det beskrevet seponeringssymptomer i form av insomni, hodepine, kvalme, diaré, influensasyndrom, nervøsitet, depresjon, smerte, svetting og svimmelhet, men ordet «abstinens» er ikke brukt. La oss kalle en spade for en spade: Pregabalin kan misbrukes.

I januar 2010 ble pregabalin oppført på Legemiddelverkets liste over legemidler under særlig overvåkning (3). Man ønsker med dette at flere tilfeller av avhengighet, overforbruk, misbruk eller seponeringsproblemer meldes som bivirkninger. Skjema for innsending av bivirkningsmelding og veiledning for utfylling finner man på www.relis.no.

\section{Elin Johanne Hansteen Strøm}

Lade Behandlingssenter

Trondheim

Litteratur

1. Bramness JG. Misbruk av pregabalin. Tidsskr Nor Legeforen 2010; 130: 1703-4.

2. Statens legemiddelverk. Preparatomtale (SPC) Lyrica. www.legemiddelverket.no (sist oppdatert 29.5.2009) (15.9.2010)

3. Statens legemiddelverk. Legemidler under særlig overvåkning. www.legemiddelverket.no (sist oppdatert 30.8. 2010) (15.9.2010).

\section{Redaktørens selvpålagte taushet}

«Taushet er ikke gull når den dekker over forhold det bør snakkes høyt om,» står det i redaktørens leder i Tidsskriftet nr. 16/2010 (1). Der presiseres det at Tidsskriftet nå har løftet meningsutvekslingen frem ved å samle ledere og debattinnlegg foran i bladet.

Men «den farlige tausheten» i Tidsskriftet representeres ikke først og fremst ved manglende debattinnlegg eller at de står langt bak i bladet, snarere ved redaktørens egen selvpålagte taushet når det gjelder å sette søkelyset på forhold det bør snakkes høyt om i norsk helsevesen.

Ett eksempel er myten om legemangel. 
Intet annet forum enn Legeforeningens eget tidsskrift ville være bedre egnet til å ta opp dette temaet. Charlotte Haug satte det selv på dagsordenen før hun ble redaktør av Tidsskriftet. På Legeforeningens ekstraordinære landsstyremøte i 1997 sa hun rett ut at vi har for mange leger her i landet. Etter hennes mening kunne vi ha klart oss med langt færre dersom vi hadde organisert helsevesenet bedre.

Haugs brannfakkel ble møtt med øredøvende taushet. I et intervju i Legekunsten påpekte hun at legene selv måtte ta ledelsen for den nødvendige omorganiseringen av helsesektoren og at de måtte basere dette på en grundig årsaksanalyse (2). Hennes poeng var at Legeforeningen ikke bare kunne rope etter flere stillinger og mer penger uten å analysere norsk helsevesen grundigere og derigjennom stille en bedre «diagnose». Det innebærer også å være åpen for alternative organisasjonsmodeller.

Siden den gang er hun blitt redaktør av Legeforeningens tidsskrift og har vært det i mange år. Hun har hatt et hav av muligheter til å sette denne og andre tabubelagte saker på dagsordenen. Men hun har selv valgt «den farlige tausheten», som har vært kjennetegnende for Tidsskriftet.

Et av de mest eklatante eksempler på Tidsskriftets «selvpålagte taushet» er den manglende interesse for privat spesialisthelsetjeneste. Dette var hovedårsaken til at tidsskriftet Legekunsten ble etablert for 20 år siden. Ifølge Legekunstens gründer, nå avdøde stifter og eier av Sentrum Røntgeninstitutt radiolog Roy Magnus Løken, «var det vanskelig - for ikke å si umulig å få våre synspunkter inn i Tidsskriftet. Det var således aldri noen innspill om den gryende, dynamiske og effektive spesialisthelsetjenesten utenfor sykehus» (3).

Denne «tausheten» eller den «politiske korrektheten», som preget Tidsskriftet også før Haugs tid, har etter min mening vært med på å hindre en helt nødvendig debatt om utviklingen av en bærekraftig spesialisthelsetjeneste.

\section{Anne Beth Moslet \\ Rykkinn}

\section{Litteratur}

1. Haug C, Bjerkestrand S. Den farlige tausheten. Tidsskr Nor Legeforen 2010; 130: 1593.

2. Moslet AB. Kan klare oss med langt færre leger Legekunsten 1997; nr. 3.

3. Moslet AB. Man ville ikke provosere. Legekunsten 2000; nr. 2.

\section{Fremdeles uklart om screening}

Jeg har i et kommentarinnlegg i Tidsskriftet nr. 16/2010 (1) minnet om nødvendigheten av å informere saklig og balansert for å innfri forutsetningene om informert samtykke når forebyggende helsetjenester tilbys. Jeg etter- lyste i samme innlegg refleksjon om grunnlaget for det forebyggende folkehelsearbeidet og påpekte at ensidig vekt på sykdom som objekt for teknologisk inngripen kan føre til at vi får et økende problem med vår selvforståelse i samfunnet. Jeg kan ikke se at Geir Hoff \& Michael Bretthauer eller Bjørn-Inge Larsen tar opp disse spørsmålene i sine leserinnlegg i Tidsskriftet nr. 21/2010 (2, 3).

Jeg er selvfølgelig glad for at helsedirektøren ønsker å belyse denne saken mer inngående. Det er på tide - men hvorfor fortalte han da norske TV-seere at et screeningprogram for kolorektal kreft kunne spare 270 liv årlig allerede i vår? Jeg er heller ikke motstander av at det knyttes forskningsprogrammer til nye helsetjenestetiltak, slik Bretthauer \& Hoff foreslår. Det er nødvendig å undersøke om intervensjoner som har vist seg effektive under kontrollerte betingelser også holder mål i samfunnet.

Men helsedirektøren svarer ikke på min hovedbekymring - nemlig at vi har screeningprogrammer i dette land som innebærer grov feilinformasjon av publikum. Legeforeningens etiske råd har rettet kritikk mot slik feilinformasjon fra private aktører (4), men vil ikke behandle helsetjenester som er innført etter politiske vedtak (5). Dette er ikke tilfredsstillende. Dersom screening for kolorektal kreft innføres som helsetjenestetiltak, er det maktpåliggende å sørge for at informasjonen klargjør at dødelighetsreduksjonen gjelder kolorektalkreft. Den sparer ingen liv. Det gjør heller ikke mammografiscreening.

Jeg er klar over at folkehelsearbeid i moderne industriland, med allment tilgjengelige og teknologisk spesialiserte helsetjenester, er vanskelig. Helsetjenestene er blitt mer tvetydige, og grensen mellom tjenester og «bjørnetjenester» er vanskelig å få øye på. Samfunnet preges av mektige aktører med økonomiske interesser knyttet til de prioriteringer som helsemyndighetene foretar. Ensidig vektlegging av vitenskapelig dokumentasjon av teknologi og kunnskapsbasert medisin som styringsredskap gjør at vi ikke ser skogen for bare trær.

Vi har store utfordringer med sykelighet og funksjonssvikt vi ikke forstår; med sosiale ulikheter i helse og mestringsevne, med manglende evne til prioritering mellom primær- og spesialisthelsetjenesten, med en aldrende befolkning, med marginalisering fra yrkeslivet og derav følgende lidelse og med finansieringsproblemer når det gjelder velferdsgodene. Jeg håper at helsemyndighetene derfor har en stadig pågående selvrefleksjon om hvilken rolle og hvilken grunnlagsforståelse de arbeider ut fra. Det hadde ikke skadet om en slik refleksjon også var synlig i Tidsskriftets spalter. Samfunnsmedisinens fremtid er avhengig av en åpen og informert dialog med fotfolket i medisinen.

\section{Eivind Meland}

Bergen
Litteratur

1. Meland E. Screening for kolorektal kreft. Tidsskr Nor Legeforen 2010; 130: 1598

2. Hoff G, Bretthauer M. Screening for kolorektalkreft - endelig en debattant! Tidsskr Nor Legeforen 2010; 130: 2012

3. Larsen B-I. Screening for kolorektal kreft. Tidsskr Nor Legeforen 2010; 130: 2012-3.

Markestad T. Markedsføring på ville veier. Tidsskr Nor Legeforen 2010; 130: 1501

5. Aas T, Markestad T. Informasjonen før screening Tidsskr Nor Lægeforen 2007; 127: 2705.

\section{Manglende troverdighet i Oslo universitetssykehus}

I Tidsskriftet nr. 19/2010 kritiserer Tor Ingebrigtsen redaktørens omtale av et diskusjonsmøte han ikke selv var til stede på (1). Møtet i Oslo legeforening handlet om Oslo universitetssykehus (OUS). Utover å ta prosessene i sykehuset på kornet var redaktørens omtale fortrøstningsfull for de mange av oss som er frustrert, forbannet og ulykkelig over det som skjer med tre gode sykehus. Videre fikk mange erfare at vi ikke var alene om frustrasjonen. Thoresen og Dolva klarte ikke å overbevise om det smarte eller økonomisk fordelaktige med å lage et gigantsykehus. Det kan skyldes at oppgaven er umulig.

Henvisningen til Orwell er glimrende. Oslo universitetssykehus er en gullgruve for nyspråk, floskler og honnørord. En nyskapning i norske sykehus er programkontoret, hvor svært mye bestemmes i praksis. Når en sak er «på plan», betyr det på vanlig norsk at den er i rute. Vi bombarderes med «gode dialoger» og «sterke forankringer» mens følelsen av avmakt øker. «Redesign» er nå blitt et standarduttrykk. Nye, uklare og mye brukte begreper skaper avstand. En sykepleier sa: «Vi lever i et papegøyokrati.»

Mange opplever sprik mellom sykehusledelsens ord og deres gjerninger. Det er trolig hovedårsaken til manglende troverdighet og det høye frustrasjonsnivået. Tidlig ble prosessen fremstilt som et faglig løft, en stimulans til de ansatte og en bedring for pasientene - en kvalitetsreform. Senere har det meste dreid seg om innsparinger. Børsspråk er blitt sykehusspråk hvor kan vi hente kjappe gevinster? Det henvises til den overordnede myndighets «bestilling». Om dette kravet til kostnadsreduksjon hadde vært presentert som det vesentligste, hadde dialogen vært enklere. «En dør inn» var et slagord fra administrasjonen våren 2009. Det ble laget en dyr reklamefilm for å anskueliggjøre viktigheten av Oslo universitetssykehus for ambulansepersonalet. Nå er adressekaoset et faktum. På glanset papir, gjerne med bilde av direktøren, har vi kunnet lese hvor godt det går i Oslo universitetssykehus. Få kjenner seg igjen. Direktøren fremholder Darwin. Er det virkelig viktigere med de til- 